\title{
Status Update on Bioelectrochemical Systems: Prospects for Carbon Electrode Design and Scale-Up
}

\author{
Katharina Herkendell
}

check for

updates

Citation: Herkendell, K. Status Update on Bioelectrochemical Systems: Prospects for Carbon Electrode Design and Scale-Up. Catalysts 2021, 11, 278. https:// doi.org/10.3390/catal11020278

Academic Editor: Barbara Mecheri

Received: 31 January 2021

Accepted: 15 February 2021

Published: 19 February 2021

Publisher's Note: MDPI stays neutral with regard to jurisdictional claims in published maps and institutional affiliations.

Copyright: (c) 2021 by the author Licensee MDPI, Basel, Switzerland. This article is an open access article distributed under the terms and conditions of the Creative Commons Attribution (CC BY) license (https:// creativecommons.org/licenses/by/ $4.0 /)$.
Department of Chemical and Biological Engineering, Friedrich-Alexander-Universität Erlangen-Nürnberg, Fürther Straße 244f, D-90429 Nürnberg, Germany; katharina.herkendell@fau.de

\begin{abstract}
Bioelectrochemical systems (BES) employ enzymes, subcellular structures or whole electroactive microorganisms as biocatalysts for energy conversion purposes, such as the electrosynthesis of value-added chemicals and power generation in biofuel cells. From a bioelectrode engineering viewpoint, customizable nanostructured carbonaceous matrices have recently received considerable scientific attention as promising electrode supports due to their unique properties attractive to bioelectronics devices. This review demonstrates the latest advances in the application of nano- and micro-structured carbon electrode assemblies in BES. Specifically, in view of the gradual increase in the commercial applicability of these systems, we aim to address the stability and scalability of different BES designs and to highlight their potential roles in a circular bioeconomy.
\end{abstract}

Keywords: mesoporous carbon; nanostructures; biofuel cells; bioelectrocatalysis; enzyme; bioenergy; bioelectrode; electrosynthesis; microorganisms; waste valorization; bioeconomy

\section{Current Developments}

Bioelectrochemical systems (BES) are made of biocatalytic assemblies capable of converting electrical into chemical energy or vice-versa. The advantages of biocatalysts in electrochemical conversion are numerous and include the possibility to work under mild operating conditions with high substrate selectivity accompanied with resilience to the presence of impurities, and the ability to seamlessly integrate decentralized energy conversion concepts [1-9]. The substitution or complementation of chemically catalyzed processes with biocatalysis are envisaged to make a multidimensional impact in the bioeconomy [10-13], where the latter has been defined by the European Commission as "the production of renewable biological resources and the conversion of these resources and waste streams into value added products, such as food, feed, bio-based products and bioenergy" [14]. From a general standpoint, BES may play a major role in a circular bioeconomy: (i) as biodegradable tools, (ii) consequential to their assembly from renewable or recycled resources, and (iii) by their conjugation to energy reco99very processes.

In regard to the first contribution (i), single-use and short-lifetime BES devices demonstrate clear opportunities in plastic/electronic waste reduction, which may be applied to biodegradable medical implants, environmental sensors, and wearable devices [15]. These include, for example, cellulose-fiber-based sensors and fuel cell components [16,17], or degradable fuel cell stacks [18].

In terms of the second role suggested for the BES (ii), intensive efforts are currently invested in developing practical approaches reducing the environmental impact of BES components by using renewable or recycled materials and energy resources. For example, Hernandez-Flores et al. introduced an agar-containing membrane for microbial electrosynthesis cells, which was discovered to be a low-cost and sustainable replacement for conventional membranes, and also resulted in a safer pretreatment procedure [14]. In another interesting recycling approach reported, high-performance microbial fuel cell electrodes were produced from waste tires [19]. 
With this in mind, it is expected that the biggest contribution of the BES to circular processes lies in the energy recovery area (iii) $[15,20,21]$. As sketched in Figure 1, the two major contributing systems recognized in the field of BES, are: (A) biofuel cells, enabling sustainable power generation from organic waste, sewage sludge, or lignocellulosic biomass [14,21,22], and (B) bioelectrosynthesis cells utilizing electrical energy to biocatalyze chemical transformations. Bioelectrosynthesis can be optimally achieved by using a feed of surplus renewable energy for the on-site production of value-added chemicals (VACs) such as hydrogen, methane, methanol, formate, or bicarbonate [23-26]. For both the biofuel and the electrosynthesis cell cases, a scalable bioelectrocatalytic production that requires high stability and efficiency of the microscopic electrode processes is essential.

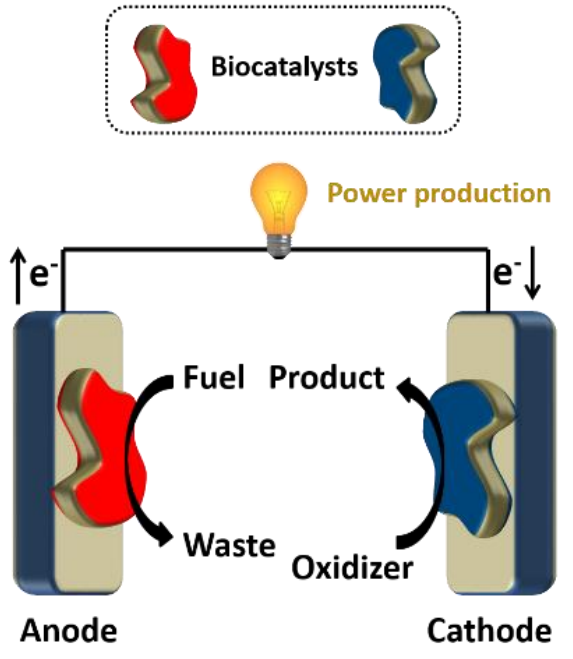

(A)

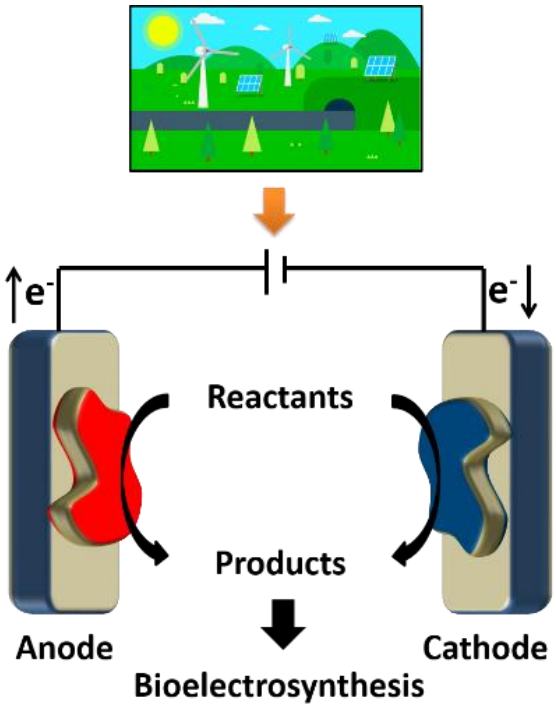

(B)

Figure 1. Illustration of the two main bioelectrochemical systems used for the production of power and value-added chemicals and their basic operation principles: (A) In the biofuel cell assembly the biocatalyzed oxidation of substrates on the anode occurring simultaneously with the cathodic reduction of an oxidizer accounts for the generation of an electric power; (B) the bioelectrosynthesis cell converts the power it is fed from renewable sources to value-added chemicals via biocatalyzed cathodic transformations.

In the process of designing a BES, one may select a biocatalyst from a constantly expanding pool of options [27]. Depending on the targeted substrate, product, and process specifications, broad possibilities to select from exist, and these include, for example: purified redox enzymes such as oxidoreductases, unpurified "crude" extracts of microbial cells, organelles such as chloroplasts or mitochondria, or whole cells such as electroactive bacteria, archaea or eukaryotes in mono- or co-cultures, given they can be immobilized in a way that allows them to effectively exchange electrons with an electrode surface in a receiving (cathodic) or ejecting (anodic) manner $[1,27,28]$. These are typically integrated into assemblies representing the four main BES categories, which consist of enzymatic fuel cells, microbial fuel cells, enzymatic electrosynthesis cells, and microbial electrosynthesis cells. While microbial systems are generally considered more stable and reliable in terms of energy or VAC recovery from organic wastes and wastewater streams, enzymatic systems benefit from high efficiencies due to the lack of membranes and metabolic processes that increase the inherent overpotentials and limited efficiencies associated with whole-cell microbial systems [29-31]. Outside of these main categories, biomimetic systems are further promising objectives for optimization $[1,13,27]$, and specific target systems such as microbial desalination and solar cells can be indicated as rapidly emerging technologies [32-34]. 
Along with the fundamental biocatalyst-electrode support interactions and electron transfer routes becoming better understood by the scientific community, the progress of the lab-scale research in this field requires an assessment of scalability and commercial applicability. Whereas substantial efforts are currently being invested in improving the performance of biocatalysts, other factors, such as the composition and the surface functionalization of the electrode show manifold possibilities for improvement. In this regard, the efficiency (i.e., rate) of the electron transfer between the catalysts and the electrodes defines the resulting space-time-yield/power density performance of the systems [1].

\section{Recent Highlights in Carbon Bioelectrodes}

In search of appropriate materials that (i) provide a stable immobilization matrix for biocatalysts, (ii) efficiently transfer electrons to/from their active centers, and (iii) are economically beneficial, carbon-based materials and additives offer a broad topographical diversity and opportunities for surface chemistry functionalization [35-38]. Compared to most metallic electrodes, carbonaceous structures naturally offer much higher specific surface areas and adsorption characteristics for biocatalyst immobilization [1,39-42].

Furthermore, whereas non-precious metals are prone to corrosion and passivation, precious metals are hard and expensive to obtain, with these efforts often leaving negative social and environmental impacts. In comparison, a great deal of scientific efforts are invested into the sustainable production of carbon nanomaterials for electrodes that can be customized in size and shape as needed [43-50].

Additionally, current advances in material science and nanofabrication allow the synthesis-dependent scaling and tuning of carbon electrode materials suitable to match specific biological component dimensions, thus potentially increasing the catalytic performance of such biocatalysts in integrated assemblies [46].

\subsection{Enzymatic Electrode Designs}

One of the major challenges in enzyme-based bioelectronics is the electrical connection, known as "wiring", between the redox enzyme's active center, which is typically buried in the electrically insulating protein, and the electrode surface. Since the beginning of bioelectrochemical research in the field, numerous studies have highlighted the promising merits of carbonaceous materials to serve as efficient matrices for enzyme immobilization and wiring. A clear distinction is commonly accepted between direct electron transfer (DET) and mediated electron transfer (MET) routes. While most redox enzymes can only communicate with the electrode supports via mediating electroactive units, certain protein structures such as bilirubin oxidase (BOD) and fructose dehydrogenase (FDH) are known to facilitate direct electron exchange in engineered electrode configurations [51,52]. Such direct configurations obviate the need to use potentially leaking mediators and reduce toxicity. They tend to support more integrated assemblies, requiring fewer components to operate. A recent review by Xia et al. discusses current wiring and surface modification techniques used in optimizing enzyme-electrode interface supporting DET [53]. Here, we set the focus on mesoporous carbon, which has been repeatedly demonstrated as a highsurface-area, conductive, biocompatible, and cheap material showing a tunable structural versatility for both MET and DET wiring strategies [54-58].

One of the advantages of the mesoporous carbon lies in the dimensions of its pores $(2-50 \mathrm{~nm})$. As the pores fall in the size range of most redox enzymes $(\sim 5-100 \mathrm{~nm})$, unique features for enzymatic biosensors, fuel cells, and electrolysis cells are expected from the carbon/enzyme hybrids. The optimal size range of the pores was further emphasized in other studies, showing that matrices with micropores $(\mathrm{d}<2 \mathrm{~nm})$ increased diffusion limitations within the electrolyte, while macropores $(\mathrm{d}>50 \mathrm{~nm})$ supported a lower surface loading of the enzyme biocatalyst [59-61]. Such drawbacks were found to be absent in the presence of the mesoporous materials, thus making them attractive for all scales of BES [62-65]. Further recent studies in the related field of enzymatic biosensors indicated that mesoporous carbon can be successfully implemented as a host matrix in amperometric 
devices [66-70], immunosensors [71], and electrochemiluminescent sensors [72]. These were subsequently used for environmental applications such as pollution detection [72-75], compost bioremediation [76], and in the health and food industries [77-79].

In 2010, Kwon et al. reported the improved stability and electron transfer characteristics observed for functionalized bioelectrodes, which were obtained by immobilizing glucose oxidase (GOx) in the pores of a mesoporous carbon matrix with a narrowing "bottleneck" pore structure [80]. This inspired the development of different "entrapment" techniques that were based on matching the pore sizes of the host matrix to the dimensions of different enzymes such as bilirubin oxidase (BOD) [81] or hemoglobin [82]. Using this approach, the immobilized enzymes showed superior stability and electroactivity when compared to other carbonaceous hosts or non-matching pore size assemblies [83]. The increased stability was attributed to the "biocompatible microenvironment" confinement leading to decreased biofouling effects [84], while the increase in the bioelectrocatalytic responses was attributed to the catalytically favorable unfolding of the protein's tertiary structure, allowing a favorable electron transfer between the cofactors of the enzymes and the pores $[80,85]$.

A novel methodology to electrically wire redox enzymes on mesoporous conductive carbon supports was shown in 2013 [86]. In the first step, a contact adsorption of mesoporous carbon nanoparticles (mpCNPs) with an average pore size of $6 \mathrm{~nm}$ was carried out on top of a glassy carbon support. The matrix was then interacted with redox-relay molecules, such as ferrocene methanol $(\mathrm{FcMeOH})$, methylene blue $\left(\mathrm{MB}^{+}\right)$, or 2,2'-azinobis (3-ethylbenzothiazoline-6-sulphonic acid) $\left(\mathrm{ABTS}^{2-}\right.$ ), which are known to mediate the enzymes GOx, horseradish peroxidase (HRP), and BOD, respectively. The subsequent adsorption of these enzymes on the matrix, followed by a chemical crosslinking and immobilization of the protein units using Nafion ${ }^{\mathrm{TM}}$, led to stable assemblies in which the enzymes capped the relay molecule-filled nanopores. As an example, the GOx-capped FcMeOH-containing mpCNP assembly is illustrated in Figure 2A. Following the observation that only a minor leakage of mediator molecules occurs from the matrix, this assembly was tested as a bioelectrocatalytic anode, as shown in Figure 2B. Evidently, the glucose-responsive anodic currents, mediated by the $\mathrm{FcMeOH}$ species trapped in the pores, showed a linear increase before their saturation at $60 \mathrm{mM}$ glucose, as shown in Figure $2 \mathrm{C}$. From the saturation current and the enzymatic loading of GOx on the surface, a turnover rate of $k_{\text {et }} \sim 1000 \mathrm{~s}^{-1}$ was calculated for the assembly. This value, nearly $50 \%$ larger than the transfer rate between GOx and its native $\mathrm{O}_{2}$ acceptor, was rationalized by the efficient electron exchange between the mpCNPs matrix and the FAD cofactor of the enzyme through the nanopore-confined diffusion of the mediator units. The generic wiring paradigm was further implemented to other enzymes, such as BOD, in the construction of an ABTS ${ }^{2-}$ /BOD-mpCNPs cathode assembly. The latter was coupled to the GOx-based anode to provide a fully functional membrane-less biofuel cell operated by glucose and $\mathrm{O}_{2}$, and supporting a power output of nearly $100 \mu \mathrm{W} \mathrm{cm}{ }^{-2}$. The enzyme-capped mpCNPimmobilization approach was further implemented in architectures employing multiple enzymes $[87,88]$. Electrodes modified with mixed compositions of redox enzymes were demonstrated to effectively conduct multiple anodic and/or cathodic bioelectrocatalytic transformations. In one system employing two redox relay units, $\mathrm{FcMeOH}$ and $\mathrm{MB}^{+}$, trapped in the nanopores by a mixture of GOx and HRP, electrocatalytic currents were observed both for the oxidation of glucose and the reduction of $\mathrm{H}_{2} \mathrm{O}_{2}$. The presence of $\mathrm{FcMeOH}$ was further shown to simultaneously mediate the two FAD-containing enzymes GOx and lactate oxidase, resulting in oxidation currents in the presence of one or both of the sugar fuels glucose and lactate. Notably, these electrically contacted bienzymefunctionalized mpCNP electrodes show promise to be applied in applications such as a dual amperometric biosensors, as well as in a multifuel-driven biofuel cells, as depicted in Figure 2D [87]. The cathodes employed in these multi-sugar fuel cells are based on ABTS $^{2-}$-loaded mpCNPs matrices capped by the BOD and catalase (CAT) enzymes. For them, two cathodic pathways were associated: (a) aerobic, at which the $4 \mathrm{e}^{-}$reduction of $\mathrm{O}_{2}$ 
to $\mathrm{H}_{2} \mathrm{O}$ was catalyzed by BOD through a pore-confined mediation by the ABTS'- species, and (b) anaerobic, at which introduction of $\mathrm{H}_{2} \mathrm{O}_{2}$ to the electrolyte in the absence of $\mathrm{O}_{2}$ led to its catalytic disproportionation to $\mathrm{O}_{2}$ and $\mathrm{H}_{2} \mathrm{O}$ by the CAT, with the generated $\mathrm{O}_{2}$ triggering the electrocatalytic transformations at the BOD. Whenever both $\mathrm{O}_{2}$ and $\mathrm{H}_{2} \mathrm{O}_{2}$ (as an internal oxygen source) were present in the cell, the power output depended on the composition of the fuel introduced into the chamber, as shown in Figure 2E. Typical power discharge curves were obtained in the presence of either glucose or lactate, with a maximal current response recorded upon the introduction of both fuels. The power outputs correlated with the relative bioelectrocatalytic responses measured for the different fuels on the anode assembly. The effect of the oxidizer composition in the cell on its maximal power output was also demonstrated, as measured in the presence, separately and combined, of the fuels in Figure 2F. Interestingly, when $\mathrm{H}_{2} \mathrm{O}_{2}$ was solely present in the electrolyte, the power generation reached peak values that were correlated to the localized formation of $\mathrm{O}_{2}$ near the BOD, avoiding its interference to the buildup of the catalytic current at the anode surface. The co-immobilization techniques were highlighted as promising for harnessing electrical power from mixed biomass environments containing multiple fuel resources.

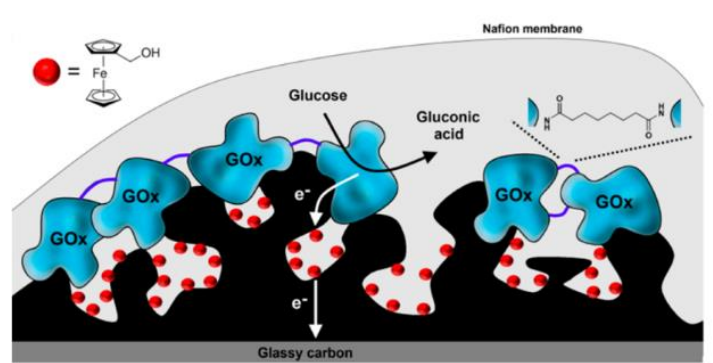

(A)

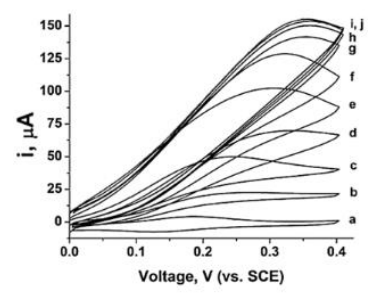

(B)

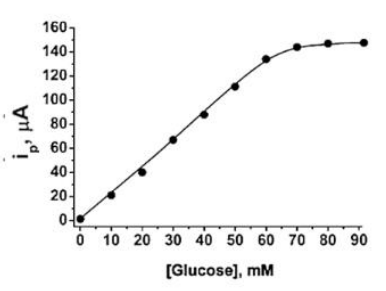

(C)

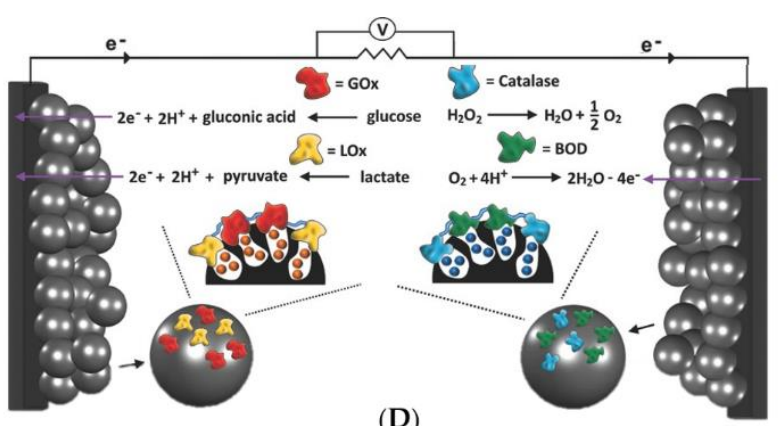

(D)

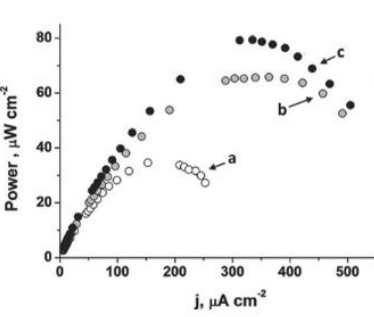

(E)

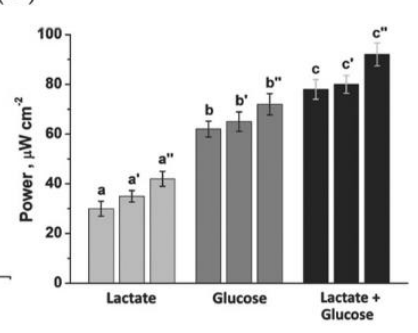

(F)

Figure 2. (A) Illustration of a glucose oxidase (GOx)-capped ferrocene methanol-loaded mesoporous carbon nanoparticle (mpCNP) assembly for the bioelectrocatalytic oxidation of glucose; (B) cyclic voltammograms corresponding to the oxidation of different concentrations of glucose $(\mathrm{a}=0 \mathrm{mM}$ to $\mathrm{j}=90 \mathrm{mM}$ in $10 \mathrm{mM}$ steps) on the electrode assembly in (A); (C) a calibration curve indicating the amperometric responses of (B) at $0.4 \mathrm{~V}$ as a function of the glucose concentration in the electrolyte; (D) illustration of a mpCNP-based multi-enzyme operated biofuel cell; (E) power output curves recorded for the cell in (D) in the presence of (a) lactate, (b) glucose, and (c) lactate and glucose. An $\mathrm{O}_{2}$-saturated HEPES buffer electrolyte containing $\mathrm{H}_{2} \mathrm{O}_{2}$ was employed; (F) maximal power outputs measured in the presence of lactate, glucose, or their mixture, in electrolytes containing the oxidizers: $(a, b, c) \mathrm{O}_{2},\left(a^{\prime}, b^{\prime}, c^{\prime}\right) \mathrm{O}_{2}+\mathrm{H}_{2} \mathrm{O}_{2}$, and $\left(a^{\prime \prime}, b^{\prime \prime}, c^{\prime \prime}\right) \mathrm{N}_{2}+\mathrm{H}_{2} \mathrm{O}_{2}$. Parts $(\mathbf{A}-\mathrm{C})$ were adapted and reprinted with permission from [86]; Copyright 2013 American Chemical Society. Parts (D-F) were adapted and reprinted with permission from [87]; copyright 2015 WILEY-VCH Verlag GmbH and Co. KGaA, Weinheim. BOD: bilirubin oxidase.

In a later study, the pore-entrapment methodology was found to be of a further benefit in the efforts to immobilize communicating enzymatic cascades on electrodes $[30,41,89,90]$. A mpCNP-entrapped enzymatic cascade-functionalized assembly was designed consisting of invertase (INV), mutarotase, GOx, and FDH [88]. When triggered in the presence of a sugar mixture (glucose, fructose, sucrose) and hydrogen peroxide, the biofuel cell allowed several sequential conversion pathways between the enzymatic catalysts, which resulted in 
an anodic biocurrent formation, and the splitting of FDH. The power output of the cascaded biofuel cell reached a peak power density of $250 \mu \mathrm{W} \mathrm{cm}-2$ and demonstrated an open circuit potential of $0.65 \mathrm{~V}$. Furthermore, the biofuel cell exhibited an unprecedented ability to operate under alternating aerobic and anaerobic conditions without any significant decrease in the discharge performance.

A further unique aspect of mesoporous carbon-based BES relates to the mpCNPs' versatility in serving as a matrix for the tailored electrosynthesis or biosynthesis of poreconfined metallic nanoparticles (NPs). This aspect is particularly interesting, as several studies showed that an enhanced catalysis is facilitated by mpCNP structures with embedded Ag [91], Au [92-96], Pt [97-99], or Pd NPs [99]. In one example, Au NP-ordered mesoporous carbon hybrid electrodes were designed by Korani et al., where the respective modification of the cathodic and anodic assemblies with a BOD and glucose dehydrogenase biocatalysts yielded a biofuel cell with a maximum power density of $33 \mu \mathrm{W} \mathrm{cm}{ }^{-2}$ [93].

Recently, carbonaceous mesoporous materials are being increasingly explored as matrices assisting DET in bioelectrocatalytic processes [53,82,100]. In one of the first examples, metal nanoparticle-mpCNP hybrid structures were tested in an assembly in which the enzymes served as caps, trapping metal ion molecules inside the mesopores [96]. Figure $3 \mathrm{~A}$ illustrates the methodology used in constructing Pt or Au nanocluster-entrapped mpCNPs. The pores were initially loaded with platinum or gold salt solutions and capped by enzyme units. The latter were cross-linked to ensure a good mechanical stability of the assembly. In the next stage, a negative potential was applied, reducing the metal ions to their respective atoms, thus creating metallic nanoclusters (NCs) whose growth was confined to the nanopores, as shown for Pt in Figure 3B. The use of the protease proteinase $\mathrm{K}$ to remove the enzyme caps yielded an electro-active surface which was then demonstrated, e.g., with Pt NCs, to electrocatalytically reduce both $\mathrm{O}_{2}$ and $\mathrm{H}_{2} \mathrm{O}_{2}$. The study further showed that by recapping the pore-entrapped metal NCs with specific redox enzymes, an electron transport from the enzymatic cofactors through the NCs to the conductive carbonaceous matrix was facilitated and allowed an effective DET pathway for electrocatalysis. The resulting assemblies showed enhanced bioelectrocatalytic functions, either in the absence or the presence of the capping enzymes (i.e., both by the metallic NPs themselves, as well as them transferring the charge to/from the enzymes). Among the systems described in this study were GOx-capped Pt NCs/mpCNPs assemblies allowing the direct oxidation of glucose, and HRP-capped Au NCs/mpCNP assemblies facilitating the direct reduction of $\mathrm{H}_{2} \mathrm{O}_{2}$.

In search for means to exploit the mpCNP matrix in enhancing the efficiency of the DET towards even more facile bioelectrocatalysis, a strategy to self-wire GOx to its carbon-supported surface matrix was recently reported [51]. The method was inspired by previous successful attempts to enzymatically reduce metal ions at the vicinity of GOx's activated $\mathrm{FADH}_{2}$ cofactor [101]. Following the loading of glassy carbon-adsorbed $\mathrm{mpCNPs}$ with platinum ions and glucose, the nanopores were capped with GOx. Under $\mathrm{N}_{2}$-saturated anaerobic conditions, the GOx oxidized the pore-entrapped glucose, with the concurrent reduction of its oxidized FAD cofactor to $\mathrm{FADH}_{2}$. Under these conditions, the cofactor acted as a strong reducing agent for the pore-entrapped Pt ions, thus allowing the formation of a Pt NC in its vicinity. The extension of the cluster from the cofactor towards the walls of the nanopore defined the "inside-out" growth direction associated with the enzymatic synthesis paradigm, as shown in Figure 3C, Panel I. As the clusters reached the carbon walls of the matrix, an electrical contact was established, allowing a bioelectrocatalytic DET path for GOx to oxidize its glucose substrate. The resulting electrode was investigated and compared to an "outside-in"-grown assembly obtained by the direct electrochemical deposition of mpCNP-entrapped Pt ions in the presence of GOx caps, as shown in Figure 3C, Panel II. The Pt NC/GOx-modified mpCNP assembly achieved by this methodology was shown to possess a larger nano-gap bridging the FAD cofactor of the GOx and the metal cluster, as compared to the enzymatically synthesized "inside-out" electrode. The larger gap increased the overpotential required to regenerate the 
bioelectrocatalytic reaction and led to a total decrease in the performance of the electrode towards oxidizing glucose. The differences between the two approaches were further reflected by comparative discharges of biofuel cells, employing a DET biocathode based on BOD-adsorbed mpCNPs, and the respective anodes, as shown in Figure 3D. As can be seen both from the polarization curves in Panel I, and the power outputs in Panel II, upon introduction of an equivalent concentration of glucose to the cells, the enzymatically "inside-out"-based assembly supported favorable discharge voltage and power generation. These were even higher than the values measured for a mediated assembly employing a GOx-capped FcMeOH-entrapped mpCNP anode. The results highlight a novel approach to self-wire redox enzymes immobilized to confining mesoporous carbon structures, thus allowing a maximal proximity between their redox centers and relaying NCs to support enhanced bioelectrocatalysis.

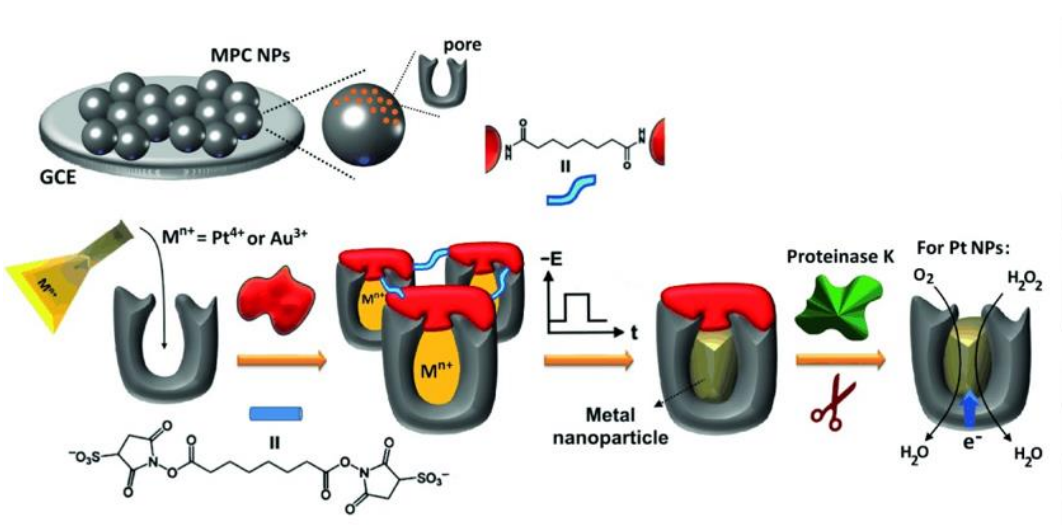

(A)

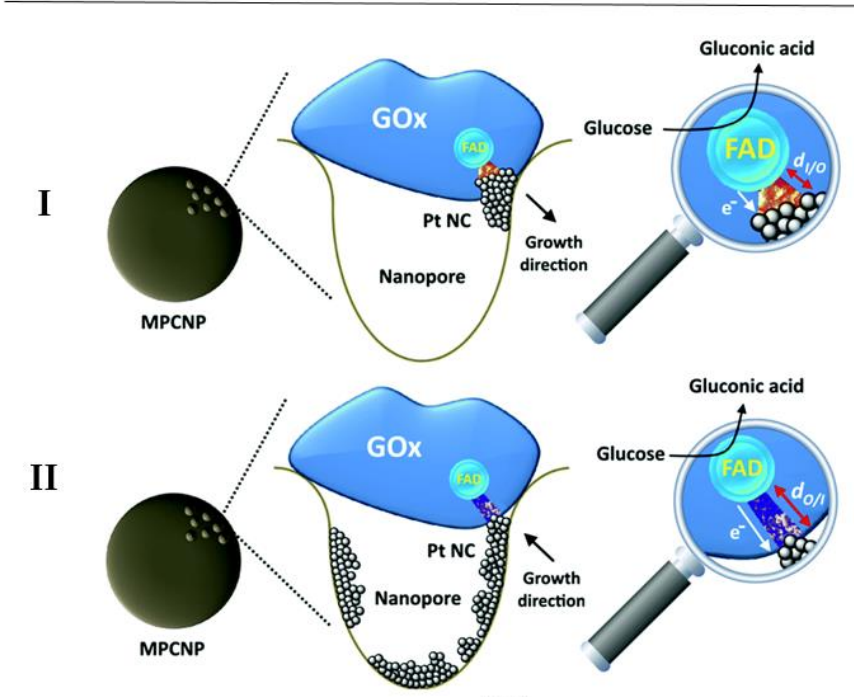

(C)

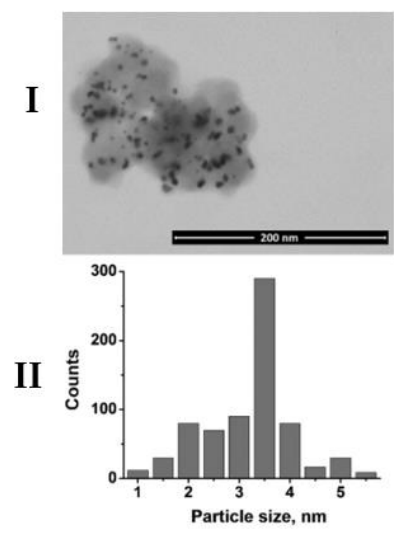

(B)

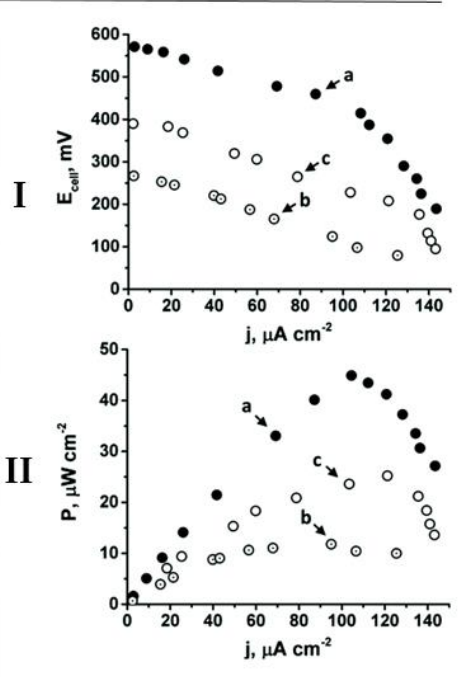

(D)

Figure 3. (A) Illustration of the methodology used to implant metallic nanoclusters in mpCNPs through enzymatic capping and electroreduction; (B) Panel I,STEM image of nanoclusters (NCs)/mpCNPs synthesized in accord with (A), Panel II, a histogram showing the size distribution of the metallic NCs in Panel I; (C) illustration of the enzymatic "inside-out" GOx/Pt NCs assembly (Panel I), and "outside-in" GOx/Pt NCs assembly (Panel II), wiring GOx to a mpCNP cavity; (D) polarization curves (Panel I) and power outputs (Panel II) corresponding to the discharge of biofuel cells based on a BOD-capped mpCNPs cathode and: (a) the enzymatic "inside-out" assembly, (b) the electrochemical "outside-in" assembly, and (c) GOx-capped, ferrocene methanol-loaded mpCNP assemblies triggered with saturated $\mathrm{O}_{2}$ and glucose. Parts (A,B) reproduced with permission from [96]; Copyright 2015 WILEY-VCH Verlag GmbH and Co. KGaA, Weinheim. Parts (C,D): [51] published by The Royal Society of Chemistry. 


\subsection{Microbial Electrode Designs}

Compared to their enzymatic counterparts, fewer studies have been reported on base supports associated with defined nanostructure features for microbial electrode assemblies, until recently [102-108]. Indeed, most studies combining microbial bioelectronics with carbonaceous supports report the use of carbon macrostructures such as glassy carbon, graphite plates, carbon fiber brushes, foams, and felts [109-112]. These are typically preferred over the use of a stainless steel, hence benefitting from the biocompatibility, low cost, conductivity, and high surface area of the carbon [113-118]. Among these materials, porous carbon electrodes with varying pore sizes were successfully implemented [119-123]. A recent increase in research activity directed towards implementing 3D-nanostructure architectures for microbial electrodes indicates that the nanotopographical modification of the electrode surfaces enhance the adhesion and growth of electroactive organisms, leading to beneficial biofilm formations and superior electron transfer properties [124-130]. In one study, Chen et al. showed a biofuel cell anode employing Escherichia coli adsorbed on a custom macroporous carbon paste with a defined pore size of $400 \mathrm{~nm}$. Notably, the pore size in the assembly, constructed on a carbon felt matrix, was slightly larger than the microorganism. The controlled pore size of the porous paste was achieved by using silica spheres as templates and sucrose as a carbon precursor. Evidently, a four times higher power output $\left(160 \mu \mathrm{W} \mathrm{cm}{ }^{-2}\right)$ was measured in this configuration compared to plain carbon felt matrices. The results were explained by the size matching between the bacteria and the pore, facilitating the formation of a bacterial biofilm with superior electron transfer between the microorganisms and the surface [119]. A similar strategy was pursued by Jeon et al. in 2018, who fabricated porous carbon scaffolds with tunable pore sizes and achieved a 40-fold higher loading density of $E$. coli confinement compared to conventional 3D porous reticulated vitreous carbon scaffolds [131]. This technique might be interesting for microbial BES electrode fabrication, as the pore sizes can be tuned by the controlled growth of polystyrene spheres by dispersion polymerization, which lead to a self-assembled arraytemplate for the carbonization of a resorcinol formaldehyde gel. Accordingly, the resulting 3D porous carbon scaffolds can be customized to the size of the targeted microorganism. In a different study, a microbial fuel cell anode employing anaerobic sludge as a biocatalytic source showed a twofold increase in its power output (ca. $280 \mu \mathrm{W} \mathrm{cm}{ }^{-2}$ ) compared to an unmodified carbon cloth anode, by employing a 3D $\mathrm{N}_{2}$-doped porous carbon material fabricated using a one-step pyrolysis route [132]. In regard to BES in a circular bioeconomy, promising power outputs were recently published for coffee waste-based activated carbon matrices employing E. coli biocatalysts [133]. The power density of the assembled fuel cell exceeded the one of commercial activated carbon (ca. $390 \mu \mathrm{W} \mathrm{cm}{ }^{-2}$ as opposed to ca. $100 \mu \mathrm{W} \mathrm{cm}{ }^{-2}$ ) with a pore size adaptable to a certain degree by the amount of added $\mathrm{KOH}$ during the carbonization process. Another sustainable and cost-effective alternative for microbial BES supports with a mixture of micro-, meso- and macropores was tested with the use of activated carbon sourced from silver grass and demonstrated a power output of ca. $100 \mu \mathrm{W} \mathrm{cm} \mathrm{cm}^{-2}$ [134]. Such approaches also hold a promise for microbial electrosynthesis processes. Notably, scalable microbial electrosynthesis cells are particularly interesting for power-to-x applications, where decentrally generated excess renewable energy is stored chemically in the form of fuel molecules such as methane, known as electromethanogenesis $[135,136]$. This microbial electrosynthesis technology employing methanogenic archaea as biocatalysts that metabolize $\mathrm{CO}_{2}$ and hydrogen is quickly growing. The produced methane can be stored, injected into the existing gas grid, or used as a transportation fuel [136]. For these reasons, the methodology was recently named "bioelectrochemical power-to-gas" [11], and it is rapidly aligning with other powerto-x methodologies that are currently being investigated for electricity-enhanced biofuel production and fossil fuel substitution [137-139]. With first field tests implying a high resilience of biocatalysts under standby conditions and contaminated $\mathrm{CO}_{2}$ feeds, which are essential for a seamless operation accompanied by fluctuating solar/wind surplus 
electricity recovery and real syngas streams, this methodology is attractive and holds a promise for the future $[140,141]$.

\subsection{Applicability}

\subsubsection{Stability}

To date, the operating lifetime expectancy in all enzyme-based systems remains a major obstacle to commercialize enzyme-based BES applications, a predicament that does not apply to their microbial counterparts as the living organisms provide optimized conditions for the membrane encapsulated enzymes [30,31]. Under full load, enzymatic fuel cells charged with a single batch of active biomaterial rarely exceed a $24 \mathrm{~h}$ discharge cycle. Despite the challenge, a few attempts showing novel approaches were carried out to prolong the discharge lifetimes of the BES. In one study [142], a stack of sealed chambers containing fresh glucose dehydrogenase deposited on multi-array electrodes facilitated a continuous operation through the sequential opening of chambers. Another study [143] demonstrated the possibility to continuously supply fresh biocatalysts into the system and to maintain an active air-breathing laccase cathode over 33 days using a laccase-producing trametes versicolor fungus present in the supernatant.

A different approach that was recently presented highlights the immobilization of redox enzymes on magnetic carbon structures [144,145]. In this study, the protein degradation limitation was bypassed by magnetically assembling and exchanging the active biocatalyst layers on stationary electrodes, as shown in Figure 4A [52]. In this design, the biocatalysts FDH and BOD were immobilized on carbon-coated magnetic nanoparticles (ccMNPs), thus generating the active components of the anode and the cathode, respectively. Directed by magnetic field gradients, these nanoparticles were deposited on planar electrode surfaces, released upon degradation of the catalytic activity, and reloaded as a fresh batch to facilitate the renewal of the active biocatalysts on the surface. The method was demonstrated for a fructose/oxygen biofuel cell. The dramatic extension in the operation lifetime of the fuel cell provides a promising approach that leaves the need for exchanging the entire systems, including chambers and electrodes, redundant. Shown in Figure 4B is another ccMNP-based methodology to extend the operational lifetime of enzymatically modified electrodes. In this study, ccMNPs were used as a removable protection layer covering a $\mathrm{BOD} /$ carbon nanotubes-deposited electrode surface. Upon the magnetic attraction of the protective layer to the surface, a stable, mediatorless oxygen reduction was obtained, and even remained while testing the biocatalysts in a harmful proteolytic environment [146]. Under these conditions, a 30\% loss in the bioelectrocatalytic currents over 30 days was observed, as compared to a $100 \%$ loss in the case of the unprotected BOD electrode. Evidently, these reports imply that the immobilization of the biocatalysts on magnetic nanoparticles offers various merits to increase the applicability of BES.

\subsubsection{Substrate Flexibility}

A further aspect of BES applicability lies in the flexibility of the system to adapt to a changing substrate supply. In this regard, the high affinity and selectivity of the biocatalysts towards their substrates can be of a disadvantage when the homogenity of feed solutions change over time, a case often observed in waste water treatment plants, side-product accumulations in fermentation processes, or biomass-derived syngas feeds [147-149]. To adress this issue, a recent study suggested a methodology based on a combination of different enzyme-modified carbonaceous nanoparticles [150]. With the base-electrode modified with relay-loaded, redox enzyme-capped mpCNPs, a second layer containing predesigned enzyme-functionalized ccMNPs was introduced through an external magnetic field gradient, as shown in Figure 4C. The close proximity between the enzymes then allowed the facile conversion of the substrate, resulting in the activation of the cascade and generation of bioelectrocatalytic currents. A further demonstration of an in-situ generation of power along changing the substrate feed composition was then exemplified. Following the methodology, a multi-substrate biofuel cell consisting of a cathodic CAT/BOD cascade 
and an anodic INV/FDH was constructed. The cell was successfully operated on fructose and sucrose and their combination. Other advantages of this cell included its ability to operate reliably in anaerobic and aerobic conditions, its exclusive operation (both cathode and anode) by DET reactions, and that the power output could be magnetically controlled. The highlighted results exemplify the promising possibilities of magnetically responsive BES to be implemented in multi-biomass environments and for applications requiring bioelectrocatalytic functions under the control of non-invasive external triggers.

(A)

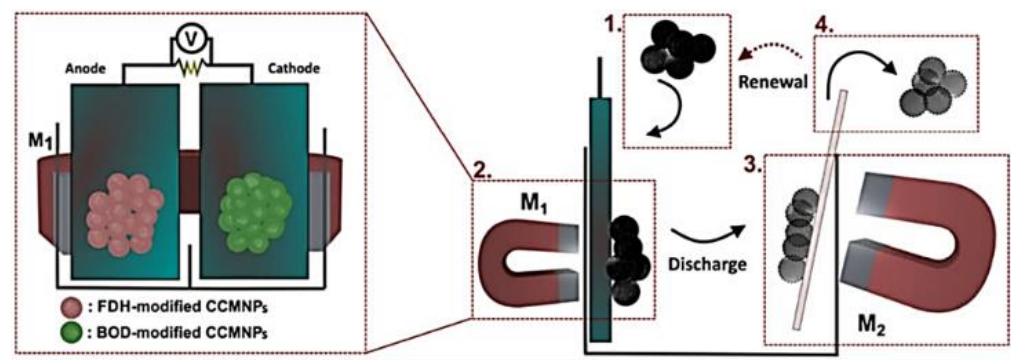

(B)

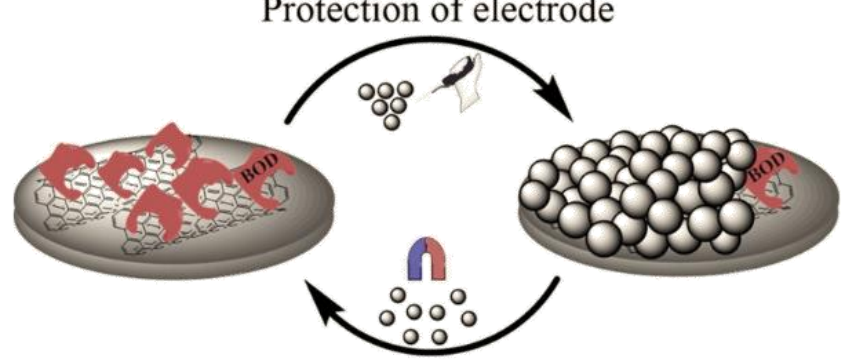

Removal of protective layer

(C)

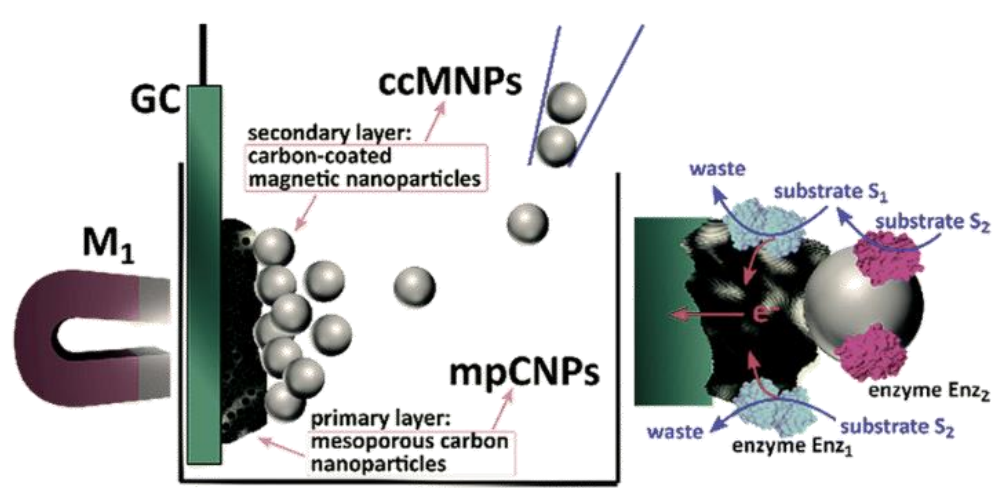

Figure 4. Illustrations of several magnetically assisted bioelectrocatalysis concepts. (A) The periodic magnetically controlled surface renewal of bioactive material immobilized on ccMNPs; (B) the protection of the bioactivity of an enzyme-adsorbed electrode through ccMNPs; (C) the activation of bioelectrocatalytic cascades by magnetic channeling of enzyme-modified ccMNPs onto the surfaces of enzyme-functionalized mpCNPs. Part (A): reprinted by permission from CCC: Springer Nature, Nano Research, Ref. [52] Copyright (C) 2021. Part (B): reprinted from [146], Copyright (C) 2021, with permission from Elsevier. Part (C): [150] published by The Royal Society of Chemistry. FDH: fructose dehydrogenase.

\section{Future Synergies}

Nanostructured carbon electrodes hold an opportunity to reduce the investment costs of manufacturing BES. This, however, might be a consequence of further research and development efforts building on the recent advancements and achievements. It can be expected, for example, that by tailoring the size of carbonaceous $3 \mathrm{D}$ architectures to the biocatalysts, the power outputs and conversion efficiencies can be further increased. 
Furthermore, the use of carbon-metallic NC hybrid structures and magnetically responsive nanostructures may contribute to biofuel cell stability and operational versatility in different environments and conditions.

The encouraging findings from fuel cell assemblies might also be translated to bioelectrosynthesis. Specifically, this knowledge transfer can be beneficial to the relatively new field of enzymatic electrosynthesis, where an increasing number of VACs are already synthesized via enzymatic routes. Among these are VACs synthesized, for example, from $\mathrm{CO}_{2}$ using single- or multi-enzymatic electrode configurations [24,25,151-153]. One may envisage that such reactions will be optimized by a tailored functionalization of nanostructured carbon electrodes, thus overcoming challenges associated with high ohmic losses, and will increase the observed low yields. A better adsorption of $\mathrm{CO}_{2}$ on nano- and microstructured support materials may also influence the transformation rates, as was recently shown with silica microspheres and their use as carrier units for immobilized carbonic anhydrase [154]. Furthermore, customized high-surface-area carbon matrices offer new possibilities for enzymatic $\mathrm{N}_{2}$ valorization [26]. Apart from classic enzymatic electrosynthesis cells, transferable electrode designs can furthermore promote the direct enzymatic conversion of sunlight [155], as well as the development of hybrid systems, which incorporate a biofuel/bioelectrosynthesis cell combination for an internal electron supply for the electrosynthesis reaction [156]. Such systems may find usage in specialized applications such as the decarbonylation of fatty aldehydes [24], or a D-sorbitol conversion [157]. For symbiotic processes, purely enzyme-based self-powered systems as well as the combination of microbial and enzymatic electrosynthesis/fuel cells are forthcoming for decentral VAC, fuel, or pharmaceutical production [24,152,155].

Interestingly, the knowledge transfer from the enzymatic systems regarding wiring and stabilization techniques may be highly valuable for the field of microbial electrosynthesis. In microbial reactor design, the unique quality of micro-/nanostructured features of the carbonaceous immobilization matrix can be successfully matched to serve a distinct purpose in the electron transfer routes $[38,158]$. Of the systems described, microbial electrosynthesis shows the highest promise for up-scaling, due to lower investment costs, self-replication and functional biofilm formation and resilience in changing operation conditions $[117,159]$.

From the current point of knowledge, the assessment of techno-economical evaluations and possible impacts on circular bioprocesses for distributed energy systems remains difficult because of limited available data $[138,160,161]$. Reliable data from scalable processes and reactor designs, in addition to regulatory developments in carbon taxing, availability of precious electrode materials, and enforcements of bioeconomic strategies, will ultimately determine the commercial competitiveness of carbon electrode-based BES technologies.

Funding: This research received no external funding.

Conflicts of Interest: The author declares no conflict of interest.

\section{References}

1. Chen, H.; Simoska, O.; Lim, K.; Grattieri, M.; Yuan, M.; Dong, F.; Lee, Y.S.; Beaver, K.; Weliwatte, S.; Gaffney, E.M.; et al. Fundamentals, applications, and future directions of bioelectrocatalysis. Chem. Rev. 2020, 120, 12903-12993. [CrossRef] [PubMed]

2. Ganiyu, S.O.; Martínez-Huitle, C.A.; Rodrigo, M.A. Renewable energies driven electrochemical wastewater/soil decontamination technologies: A critical review of fundamental concepts and applications. Appl. Catal. B Environ. 2020, 270, 118857. [CrossRef]

3. Miehe, R.; Full, J.; Scholz, P.; Demmer, A.; Bauernhansl, T.; Sauer, A.; Schuh, G. The biological transformation of industrial manufacturing-Future fields of action in bioinspired and bio-based production technologies and organization. Procedia Manuf. 2019, 39, 737-744. [CrossRef]

4. Rovira-Alsina, L.; Balaguer, M.D.; Puig, S. Thermophilic bio-electro carbon dioxide recycling harnessing renewable energy surplus. Bioresour. Technol. 2021, 321, 124423. [CrossRef] [PubMed]

5. Frijns, J.; Hofman, J.; Nederlof, M. The potential of (waste)water as energy carrier. Energy Convers. Manag. 2013, 65, 357-363. [CrossRef]

6. Ghangrekar, M.M.; Das, S.; Tiwari, B.R. Integration of bioelectrochemical systems with other existing wastewater treatment processes. In Integrated Microbial Fuel Cells for Wastewater Treatment; Elsevier: Amsterdam, The Netherlands, 2020 ; pp. 229-248. 
7. Kim, B.; Jang, N.; Lee, M.; Jang, J.K.; Chang, I.S. Microbial fuel cell driven mineral rich wastewater treatment process for circular economy by creating virtuous cycles. Bioresour. Technol. 2021, 320, 124254. [CrossRef]

8. Gude, V.G.; Kokabian, B.; Gadhamshetty, V. Beneficial bioelectrochemical systems for energy, water, and biomass production. J. Microb. Biochem. Technol. 2013, 5, 1-14. [CrossRef]

9. Berger, M. Generating energy becomes personal. In Nanotechnology: The Future is Tiny; Royal Society of Chemistry: London, UK, 2016; pp. 1-27.

10. Stegmann, P.; Londo, M.; Junginger, M. The circular bioeconomy: Its elements and role in European bioeconomy clusters. Resour. Conserv. Recycl. X 2020, 6, 100029. [CrossRef]

11. Geppert, F.; Liu, D.; van Eerten-Jansen, M.; Weidner, E.; Buisman, C.; ter Heijne, A. Bioelectrochemical power-to-gas: State of the art and future perspectives. Trends Biotechnol. 2016, 34, 879-894. [CrossRef]

12. Kano, K.; Shirai, O.; Kitazumi, Y.; Sakai, K.; Xia, H.-Q.; Kano, K.; Shirai, O.; Kitazumi, Y.; Sakai, K.; Xia, H.-Q. Applications to biofuel cells and bioreactors. In Enzymatic Bioelectrocatalysis; Springer: Singapore, 2021; pp. 115-131.

13. Costa De Oliveira, M.A.; D’Epifanio, A.; Ohnuki, H.; Mecheri, B. Platinum group metal-free catalysts for oxygen reduction reaction: Applications in microbial fuel cells. Catalysts 2020, 10, 475. [CrossRef]

14. Hernández-Flores, G.; Poggi-Varaldo, H.M.; Solorza-Feria, O. Comparison of alternative membranes to replace high cost Nafion ones in microbial fuel cells. Int. J. Hydrog. Energy 2016, 41, 23354-23362. [CrossRef]

15. Mohan, S.V.; Nikhil, G.N.; Chiranjeevi, P.; Reddy, C.N.; Rohit, M.V.; Kumar, A.N.; Sarkar, O. Waste biorefinery models towards sustainable circular bioeconomy: Critical review and future perspectives. Bioresour. Technol. 2016, 215, 2-12. [CrossRef] [PubMed]

16. Tominaga, M.; Kuwahara, K.; Tsushida, M.; Shida, K. Cellulose nanofiber-based electrode as a component of an enzyme-catalyzed biofuel cell. RSC Adv. 2020, 10, 22120-22125. [CrossRef]

17. González-Pabón, M.J.; Cardeña, R.; Cortón, E.; Buitrón, G. Hydrogen production in two-chamber MEC using a low-cost and biodegradable poly(vinyl) alcohol/chitosan membrane. Bioresour. Technol. 2021, 319, 124168. [CrossRef]

18. Winfield, J.; Chambers, L.D.; Rossiter, J.; Stinchcombe, A.; Walter, X.A.; Greenman, J.; Ieropoulos, I. Fade to green: A biodegradable stack of microbial fuel cells. ChemSusChem 2015, 8, 2705-2712. [CrossRef]

19. Chen, W.; Feng, H.; Shen, D.; Jia, Y.; Li, N.; Ying, X.; Chen, T.; Zhou, Y.; Guo, J.; Zhou, M. Carbon materials derived from waste tires as high-performance anodes in microbial fuel cells. Sci. Total Environ. 2018, 618, 804-809. [CrossRef]

20. Miran, W.; Nawaz, M.; Jang, J.; Lee, D.S. Sustainable electricity generation by biodegradation of low-cost lemon peel biomass in a dual chamber microbial fuel cell. Int. Biodeterior. Biodegrad. 2016, 106, 75-79. [CrossRef]

21. Jiang, Y.; May, H.D.; Lu, L.; Liang, P.; Huang, X.; Ren, Z.J. Carbon dioxide and organic waste valorization by microbial electrosynthesis and electro-fermentation. Water Res. 2019, 149, 42-55. [CrossRef]

22. Jafary, T.; Ghasemi, M.; Alam, J.; Aljlil, S.A.; Yusup, S. Carbon-based polymer nanocomposites as electrodes for microbial fuel cells. In Carbon-Based Polymer Nanocomposites for Environmental and Energy Applications; Elsevier Inc.: Amsterdam, The Netherlands, 2018; pp. 361-390.

23. Roy, S.; Schievano, A.; Pant, D. Electro-stimulated microbial factory for value added product synthesis. Bioresour. Technol. 2015, 213, 129-139. [CrossRef]

24. Mohanakrishna, G.; Kondaveeti, S.; Desale, P.; El Mekawy, A.; Abu-Reesh, I.M. Enzymatic electrosynthesis toward value addition. In Biomass, Biofuels, Biochemicals: Microbial Electrochemical Technology: Sustainable Platform for Fuels, Chemicals and Remediation; Elsevier: Amsterdam, The Netherlands, 2018; pp. 955-973.

25. Srikanth, S.; Maesen, M.; Dominguez-Benetton, X.; Vanbroekhoven, K.; Pant, D. Enzymatic electrosynthesis of formate through CO2 sequestration/reduction in a bioelectrochemical system (BES). Bioresour. Technol. 2014, 165, 350-354. [CrossRef]

26. $\mathrm{Wu}, \mathrm{R}$; Ma, C.; Zhu, Z. Enzymatic electrosynthesis as an emerging electrochemical synthesis platform. Curr. Opin. Electrochem. 2020, 19, 1-7. [CrossRef]

27. Logan, B.E.; Rossi, R.; Ragab, A.; Saikaly, P.E. Electroactive microorganisms in bioelectrochemical systems. Nat. Rev. Microbiol. 2019, 17, 307-319. [CrossRef] [PubMed]

28. Dmitrieva, M.V.; Zolotukhina, E.V. Data describing the cofactor additives effect on bioelectrocatalytic activity of «crude» extracts. Data BR 2020, 30, 105513. [CrossRef]

29. Pant, D.; Singh, A.; Van Bogaert, G.; Irving Olsen, S.; Singh Nigam, P.; Diels, L.; Vanbroekhoven, K. Bioelectrochemical systems (BES) for sustainable energy production and product recovery from organic wastes and industrial wastewaters. RSC Adv. 2012, 2, 1248-1263. [CrossRef]

30. Lapinsonnière, L.; Picot, M.; Barrière, F. Enzymatic versus Microbial Bio-Catalyzed Electrodes in Bio-Electrochemical Systems. ChemSusChem 2012, 5, 995-1005. [CrossRef]

31. Freguia, S.; Virdis, B.; Harnisch, F.; Keller, J. Bioelectrochemical systems: Microbial versus enzymatic catalysis. Electrochim. Acta 2012, 82, 165-174. [CrossRef]

32. Liu, L.; Choi, S. Miniature microbial solar cells to power wireless sensor networks. Biosens. Bioelectron. 2021, 177, 112970. [CrossRef]

33. Guang, L.; Koomson, D.A.; Jingyu, H.; Ewusi-Mensah, D.; Miwornunyuie, N. Performance of exoelectrogenic bacteria used in microbial desalination cell technology. Int. J. Environ. Res. Public Health 2020, 17, 1121. [CrossRef]

34. Al-Mamun, A.; Ahmad, W.; Baawain, M.S.; Khadem, M.; Dhar, B.R. A review of microbial desalination cell technology: Configurations, optimization and applications. J. Clean. Prod. 2018, 183, 458-480. [CrossRef] 
35. Babadi, A.A.; Bagheri, S.; Hamid, S.B.A. Progress on implantable biofuel cell: Nano-carbon functionalization for enzyme immobilization enhancement. Biosens. Bioelectron. 2016, 79, 850-860. [CrossRef]

36. Mazurenko, I.; de Poulpiquet, A.; Lojou, E. Recent developments in high surface area bioelectrodes for enzymatic fuel cells. Curr. Opin. Electrochem. 2017, 5, 74-84. [CrossRef]

37. Palanisamy, G.; Jung, H.Y.; Sadhasivam, T.; Kurkuri, M.D.; Kim, S.C.; Roh, S.H. A comprehensive review on microbial fuel cell technologies: Processes, utilization, and advanced developments in electrodes and membranes. J. Clean. Prod. 2019, 221, 598-621. [CrossRef]

38. Guo, K.; Prévoteau, A.; Patil, S.A.; Rabaey, K. Engineering electrodes for microbial electrocatalysis. Curr. Opin. Biotechnol. 2015, 33, 149-156. [CrossRef] [PubMed]

39. Kumar, G.G.; Sarathi, V.G.S.; Nahm, K.S. Recent advances and challenges in the anode architecture and their modifications for the applications of microbial fuel cells. Biosens. Bioelectron. 2013, 43, 461-475. [CrossRef] [PubMed]

40. Hernández-Fernández, F.J.; Pérez De Los Ríos, A.; Salar-García, M.J.; Ortiz-Martínez, V.M.; Lozano-Blanco, L.J.; Godínez, C.; Tomás-Alonso, F.; Quesada-Medina, J. Recent progress and perspectives in microbial fuel cells for bioenergy generation and wastewater treatment. Fuel Process. Technol. 2015, 138, 284-297. [CrossRef]

41. Sokic-Lazic, D.; Arechederra, R.L.; Treu, B.L.; Minteer, S.D. Oxidation of biofuels: Fuel diversity and effectiveness of fuel oxidation through multiple enzyme cascades. Electroanalysis 2010, 22, 757-764. [CrossRef]

42. Gilmartin, M.A.T.; Hart, J.P. Sensing with chemically and biologically modified carbon electrodes: A review. Analyst 1995, 120, 1029-1045. [CrossRef] [PubMed]

43. Gong, K.; Yan, Y.; Zhang, M.; Su, L.; Xiong, S.; Mao, L. Electrochemistry and electroanalytical applications of carbon nanotubes: A review. Anal. Sci. 2005, 21, 1383-1393. [CrossRef] [PubMed]

44. Ravi, S.; Vadukumpully, S. Sustainable carbon nanomaterials: Recent advances and its applications in energy and environmental remediation. J. Environ. Chem. Eng. 2016, 4, 835-856. [CrossRef]

45. Jung, S.; Myung, Y.; Das, G.S.; Bhatnagar, A.; Park, J.W.; Tripathi, K.M.; Kim, T. Carbon nano-onions from waste oil for application in energy storage devices. New J. Chem. 2020, 44, 7369-7375. [CrossRef]

46. Titirici, M.M.; White, R.J.; Brun, N.; Budarin, V.L.; Su, D.S.; Del Monte, F.; Clark, J.H.; MacLachlan, M.J. Sustainable carbon materials. Chem. Soc. Rev. 2015, 44, 250-290. [CrossRef] [PubMed]

47. Panda, A.; Arumugasamy, S.K.; Lee, J.; Son, Y.; Yun, K.; Venkateswarlu, S.; Yoon, M. Chemical-free sustainable carbon nano-onion as a dual-mode sensor platform for noxious volatile organic compounds. Appl. Surf. Sci. 2021, 537, 147872. [CrossRef]

48. Licht, S.; Douglas, A.; Ren, J.; Carter, R.; Lefler, M.; Pint, C.L. Carbon nanotubes produced from ambient carbon dioxide for environmentally sustainable lithium-ion and sodium-ion battery anodes. ACS Cent. Sci. 2016, 2, 162-168. [CrossRef] [PubMed]

49. Kuzmenko, V.; Naboka, O.; Haque, M.; Staaf, H.; Göransson, G.; Gatenholm, P.; Enoksson, P. Sustainable carbon nanofibers/nanotubes composites from cellulose as electrodes for supercapacitors. Energy 2015, 90, 1490-1496. [CrossRef]

50. Lim, J.; Jin, X.; Hwang, S.J.; Scheu, C. Structural changes of 2D FexMn1-xO2 nanosheets for low-temperature growth of carbon nanotubes. Adv. Funct. Mater. 2020, 30, 2003849. [CrossRef]

51. Trifonov, A.; Stemmer, A.; Tel-Vered, R. Enzymatic self-wiring in nanopores and its application in direct electron transfer biofuel cells. Nanoscale Adv. 2019, 1, 347-356. [CrossRef]

52. Herkendell, K.; Stemmer, A.; Tel-Vered, R. Extending the operational lifetimes of all-direct electron transfer enzymatic biofuel cells by magnetically assembling and exchanging the active biocatalyst layers on stationary electrodes. Nano Res. 2019, 12, 767-775. [CrossRef]

53. Xia, H.; Zeng, J. Rational surface modification of carbon nanomaterials for improved direct electron transfer-type bioelectrocatalysis of redox enzymes. Catalysts 2020, 10, 1447. [CrossRef]

54. Kim, J.H.; Lee, D.; Bae, T.S.; Lee, Y.S. The electrochemical enzymatic glucose biosensor based on mesoporous carbon fibers activated by potassium carbonate. J. Ind. Eng. Chem. 2015, 25, 192-198. [CrossRef]

55. Fu, C.; Yi, D.; Deng, C.; Wang, X.; Zhang, W.; Tang, Y.; Caruso, F.; Wang, Y. A partially graphitic mesoporous carbon membrane with three-dimensionally networked nanotunnels for ultrasensitive electrochemical detection. Chem. Mater. 2017, 29, 5286-5293. [CrossRef]

56. Zhou, M.; Shang, L.; Li, B.; Huang, L.; Dong, S. The characteristics of highly ordered mesoporous carbons as electrode material for electrochemical sensing as compared with carbon nanotubes. Electrochem. Commun. 2008, 10, 859-863. [CrossRef]

57. Ghasemi, E.; Shams, E.; Nejad, F.N. Covalent modification of ordered mesoporous carbon with glucose oxidase for fabrication of glucose biosensor. J. Electroanal. Chem. 2015, 752, 60-67. [CrossRef]

58. Tsujimura, S.; Murata, K.; Akatsuka, W. Exceptionally high glucose current on a hierarchically structured porous carbon electrode with "wired" flavin adenine dinucleotide-dependent glucose dehydrogenase. J. Am. Chem. Soc. 2014, 136, 14432-14437. [CrossRef]

59. Tao, Y.; Kanoh, H.; Abrams, L.; Kaneko, K. Mesopore-modified zeolites: Preparation, characterization, and applications. Chem. Rev. 2006, 106, 896-910. [CrossRef] [PubMed]

60. Marthala, V.R.R.; Friedrich, M.; Zhou, Z.; Distaso, M.; Reuss, S.; Al-Thabaiti, S.A.; Peukert, W.; Schwieger, W.; Hartmann, M. Zeolite-coated porous arrays: A novel strategy for enzyme encapsulation. Adv. Funct. Mater. 2015, 25, 1832-1836. [CrossRef]

61. Hartmann, M.; Kostrov, X. Immobilization of enzymes on porous silicas-Benefits and challenges. Chem. Soc. Rev. 2013, 42, 6277-6289. [CrossRef] 
62. Caldas, E.M.; Novatzky, D.; Deon, M.; de Menezes, E.W.; Hertz, P.F.; Costa, T.M.H.; Arenas, L.T.; Benvenutti, E.V. Pore size effect in the amount of immobilized enzyme for manufacturing carbon ceramic biosensor. Microporous Mesoporous Mater. 2017, 247, 95-102. [CrossRef]

63. Funabashi, H.; Takeuchi, S.; Tsujimura, S. Hierarchical meso/macro-porous carbon fabricated from dual MgO templates for direct electron transfer enzymatic electrodes. Sci. Rep. 2017, 7, 1-9. [CrossRef] [PubMed]

64. You, C.; Xu, X.; Tian, B.; Kong, J.; Zhao, D.; Liu, B. Electrochemistry and biosensing of glucose oxidase based on mesoporous carbons with different spatially ordered dimensions. Talanta 2009, 78, 705-710. [CrossRef]

65. Bobrowski, T.; Conzuelo, F.; Ruff, A.; Hartmann, V.; Frank, A.; Erichsen, T.; Nowaczyk, M.M.; Schuhmann, W. Scalable fabrication of biophotoelectrodes by means of automated airbrush spray-coating. ChemPlusChem 2020, 85, 1396-1400. [CrossRef] [PubMed]

66. Zhu, L.; Tian, C.; Yang, D.; Jiang, X.; Yang, R. Bioanalytical application of the ordered mesoporous carbon modified electrodes. Electroanalysis 2008, 20, 2518-2525. [CrossRef]

67. Zhou, Y.; Tang, L.; Zeng, G.; Chen, J.; Wang, J.; Fan, C.; Yang, G.; Zhang, Y.; Xie, X. Amplified and selective detection of manganese peroxidase genes based on enzyme-scaffolded-gold nanoclusters and mesoporous carbon nitride. Biosens. Bioelectron. 2015, 65, 382-389. [CrossRef] [PubMed]

68. Olyveira, G.M.; Kim, J.H.; Martins, M.V.A.; Iost, R.M.; Chaudhari, K.N.; Yu, J.S.; Crespilho, F.N. Flexible carbon cloth electrode modified by hollow core-mesoporous shell carbon as a novel efficient bio-anode for biofuel cell. J. Nanosci. Nanotechnol. 2012, 12, 356-360. [CrossRef] [PubMed]

69. Tang, L.; Zhou, Y.; Zeng, G.; Li, Z.; Liu, Y.; Zhang, Y.; Chen, G.; Yang, G.; Lei, X.; Wu, M. A tyrosinase biosensor based on ordered mesoporous carbon-Au/l-lysine/Au nanoparticles for simultaneous determination of hydroquinone and catechol. Analyst 2013, 138, 3552-3560. [CrossRef]

70. Dai, M.; Haselwood, B.; Vogt, B.D.; La Belle, J.T. Amperometric sensing of norepinephrine at picomolar concentrations using screen printed, high surface area mesoporous carbon. Anal. Chim. Acta 2013, 788, 32-38. [CrossRef] [PubMed]

71. Yang, L.; Zhao, H.; Deng, G.; Ran, X.; Li, Y.; Xie, X.; Li, C.P. Immunosensor for prostate-specific antigen using Au/Pd@flower-like $\mathrm{SnO} 2$ as platform and Au@mesoporous carbon as signal amplification. RSC Adv. 2015, 5, 74046-74053. [CrossRef]

72. Zhang, Q.; Xu, G.; Gong, L.; Dai, H.; Zhang, S.; Li, Y.; Lin, Y. An enzyme-assisted electrochemiluminescent biosensor developed on order mesoporous carbons substrate for ultrasensitive glyphosate sensing. Electrochim. Acta 2015, 186, 624-630. [CrossRef]

73. Justino, C.I.L.; Duarte, A.C.; Rocha-Santos, T.A.P. Recent progress in biosensors for environmental monitoring: A review. Sensors 2017, 17, 2918. [CrossRef]

74. Wang, X.; Lu, X.; Wu, L.; Chen, J. Direct electrochemical tyrosinase biosensor based on mesoporous carbon and $\mathrm{Co}_{3} \mathrm{O}_{4} \mathrm{nanorods}$ for the rapid detection of phenolic pollutants. ChemElectroChem 2014, 1, 808-816. [CrossRef]

75. Lee, J.H.; Park, J.Y.; Min, K.; Cha, H.J.; Choi, S.S.; Yoo, Y.J. A novel organophosphorus hydrolase-based biosensor using mesoporous carbons and carbon black for the detection of organophosphate nerve agents. Biosens. Bioelectron. 2010, 25, 1566-1570. [CrossRef]

76. Zhou, Y.; Tang, L.; Zeng, G.; Chen, J.; Cai, Y.; Zhang, Y.; Yang, G.; Liu, Y.; Zhang, C.; Tang, W. Mesoporous carbon nitride based biosensor for highly sensitive and selective analysis of phenol and catechol in compost bioremediation. Biosens. Bioelectron. 2014, 61, 519-525. [CrossRef] [PubMed]

77. Kim, J.; Campbell, A.S.; de Ávila, B.E.F.; Wang, J. Wearable biosensors for healthcare monitoring. Nat. Biotechnol. 2019, 37, 389-406. [CrossRef]

78. Zeng, Y.; Zhu, Z.; Du, D.; Lin, Y. Nanomaterial-based electrochemical biosensors for food safety. J. Electroanal. Chem. 2016, 781, 147-154. [CrossRef]

79. Mello, L.D.; Kubota, L.T. Review of the use of biosensors as analytical tools in the food and drink industries. Food Chem. 2002, 77, 237-256. [CrossRef]

80. Kwon, K.Y.; Youn, J.; Kim, J.H.; Park, Y.; Jeon, C.; Kim, B.C.; Kwon, Y.; Zhao, X.; Wang, P.; Sang, B.I.; et al. Nanoscale enzyme reactors in mesoporous carbon for improved performance and lifetime of biosensors and biofuel cells. Biosens. Bioelectron. 2010, 26, 655-660. [CrossRef] [PubMed]

81. Itoh, T.; Shibuya, Y.; Yamaguchi, A.; Hoshikawa, Y.; Tanaike, O.; Tsunoda, T.; Hanaoka, T.A.; Hamakawa, S.; Mizukami, F.; Hayashi, A.; et al. High-performance bioelectrocatalysts created by immobilization of an enzyme into carbon-coated composite membranes with nano-tailored structures. J. Mater. Chem. A 2017, 5, 20244-20251. [CrossRef]

82. Habibi, B.; Jahanbakhshi, M. Direct electrochemistry of hemoglobin in a renewable mesoporous carbon ceramic electrode: A new kind of hydrogen peroxide biosensor. Microchim. Acta 2015, 182, 957-963. [CrossRef]

83. Lu, X.; Xiao, Y.; Lei, Z.; Chen, J.; Zhang, H.; Ni, Y.; Zhang, Q. A promising electrochemical biosensing platform based on graphitized ordered mesoporous carbon. J. Mater. Chem. 2009, 19, 4707-4714. [CrossRef]

84. Wu, L.; Lu, X.; Zhang, H.; Chen, J. Amino acid ionic liquid modified mesoporous carbon: A tailor-made nanostructure biosensing platform. ChemSusChem 2012, 5, 1918-1925. [CrossRef]

85. Ania, C.O.; Gomis-Berenguer, A.; Dentzer, J.; Vix-Guterl, C. Nanoconfinement of glucose oxidase on mesoporous carbon electrodes with tunable pore sizes. J. Electroanal. Chem. 2018, 808, 372-379. [CrossRef]

86. Trifonov, A.; Herkendell, K.; Tel-Vered, R.; Yehezkeli, O.; Woerner, M.; Willner, I. Enzyme-capped relay-functionalized mesoporous carbon nanoparticles: Effective bioelectrocatalytic matrices for sensing and biofuel cell applications. ACS Nano 2013, 7, 1135811368. [CrossRef] [PubMed] 
87. Trifonov, A.; Tel-Vered, R.; Fadeev, M.; Willner, I. Electrically contacted bienzyme-functionalized mesoporous carbon nanoparticle electrodes: Applications for the development of dual amperometric biosensors and multifuel-driven biofuel cells. Adv. Energy Mater. 2015, 5, 1401853. [CrossRef]

88. Herkendell, K.; Tel-Vered, R.; Stemmer, A. Switchable aerobic/anaerobic multi-substrate biofuel cell operating on anodic and cathodic enzymatic cascade assemblies. Nanoscale 2017, 9, 14118-14126. [CrossRef]

89. Guterl, J.-K.; Sieber, V. Biosynthesis “debugged”: Novel bioproduction strategies. Eng. Life Sci. 2013, 13, 4-18. [CrossRef]

90. Moehlenbrock, M.J.; Toby, T.K.; Pelster, L.N.; Minteer, S.D. Metabolon catalysts: An efficient model for multi-enzyme cascades at electrode surfaces. ChemCatChem 2011, 3, 561-570. [CrossRef]

91. Mondal, K.; Ali, M.A.; Singh, C.; Sumana, G.; Malhotra, B.D.; Sharma, A. Highly sensitive porous carbon and metal/carbon conducting nanofiber based enzymatic biosensors for triglyceride detection. Sens. Actuators B 2017, 246, 202-214. [CrossRef]

92. Sakai, K.; Kitazumi, Y.; Shirai, O.; Takagi, K.; Kano, K. Direct electron transfer-type four-way bioelectrocatalysis of $\mathrm{CO}_{2} /$ formate and NAD+/NADH redox couples by tungsten-containing formate dehydrogenase adsorbed on gold nanoparticle-embedded mesoporous carbon electrodes modified with 4-mercaptopyridine. Electrochem. Commun. 2017, 84, 75-79. [CrossRef]

93. Korani, A.; Salimi, A.; Karimi, B. Guanine/ionic liquid derived ordered mesoporous carbon decorated with AuNPs as efficient NADH biosensor and suitable platform for enzymes immobilization and biofuel cell design. Electroanalysis 2017, 29, 2646-2655. [CrossRef]

94. Liu, Z.; Xu, Q.; Fu, J.; Shi, Z.; Yang, Q.; Guo, Y.; Zhang, Y.; Sun, X.; Wang, Z. Dual-signal amplification strategy aptasensor based on exonuclease III and ordered mesoporous carbon-gold nanocomposites for tetracycline detection in milk. Int. J. Electrochem. Sci. 2018, 13, 8260-8274. [CrossRef]

95. Wang, L.; Bai, J.; Bo, X.; Zhang, X.; Guo, L. A novel glucose sensor based on ordered mesoporous carbon-Au nanoparticles nanocomposites. Talanta 2011, 83, 1386-1391. [CrossRef] [PubMed]

96. Trifonov, A.; Tel-Vered, R.; Fadeev, M.; Cecconello, A.; Willner, I. Metal nanoparticle-loaded mesoporous carbon nanoparticles: Electrical contacting of redox proteins and electrochemical sensing applications. Electroanalysis 2015, 27, 2150-2157. [CrossRef]

97. You, C.; Li, X.; Zhang, S.; Kong, J.; Zhao, D.; Liu, B. Electrochemistry and biosensing of glucose oxidase immobilized on Pt-dispersed mesoporous carbon. Microchim. Acta 2009, 167, 109-116. [CrossRef]

98. Yu, J.; Yu, D.; Zhao, T.; Zeng, B. Development of amperometric glucose biosensor through immobilizing enzyme in a Pt nanoparticles/mesoporous carbon matrix. Talanta 2008, 74, 1586-1591. [CrossRef]

99. Haghighi, B.; Karimi, B.; Tavahodi, M.; Behzadneia, H. Electrochemical behavior of glucose oxidase immobilized on Pdnanoparticles decorated ionic liquid derived fibrillated mesoporous carbon. Electroanalysis 2014, 26, 2010-2016. [CrossRef]

100. Sakai, K.; Sugimoto, Y.; Kitazumi, Y.; Shirai, O.; Takagi, K.; Kano, K. Direct electron transfer-type bioelectrocatalytic interconversion of carbon dioxide/formate and NAD+/NADH redox couples with tungsten-containing formate dehydrogenase. Electrochim. Acta 2017, 228, 537-544. [CrossRef]

101. Yehezkeli, O.; Ovits, O.; Tel-Vered, R.; Raichlin, S.; Willner, I. Reconstituted enzymes on electropolymerizable FAD-modified metallic nanoparticles: Functional units for the assembly of effectively "wired" enzyme electrodes. Electroanalysis 2010, 22, 1817-1823. [CrossRef]

102. Sonawane, J.M.; Yadav, A.; Ghosh, P.C.; Adeloju, S.B. Recent advances in the development and utilization of modern anode materials for high performance microbial fuel cells. Biosens. Bioelectron. 2017, 90, 558-576. [CrossRef]

103. Zhang, T.; Nie, H.; Bain, T.S.; Lu, H.; Cui, M.; Snoeyenbos-West, O.L.; Franks, A.E.; Nevin, K.P.; Russell, T.P.; Lovley, D.R. Improved cathode materials for microbial electrosynthesis. Energy Environ. Sci. 2013, 6, 217-224. [CrossRef]

104. Jafary, T.; Daud, W.R.W.; Ghasemi, M.; Kim, B.H.; Jahim, J.M.; Ismail, M.; Lim, S.S. Biocathode in microbial electrolysis cell; Present status and future prospects. Renew. Sustain. Energy Rev. 2015, 47, 23-33. [CrossRef]

105. Alatraktchi, F.A.A.; Zhang, Y.; Noori, J.S.; Angelidaki, I. Surface area expansion of electrodes with grass-like nanostructures and gold nanoparticles to enhance electricity generation in microbial fuel cells. Bioresour. Technol. 2012, 123, 177-183. [CrossRef] [PubMed]

106. Abada, B.; Boumerfeg, S.; Haddad, A.; Etienne, M. Electrochemical investigation of thiobacillus denitrificans in a bacterial composite. J. Electrochem. Soc. 2020, 167, 135502. [CrossRef]

107. Li, S.; Cheng, C.; Thomas, A. Carbon-based microbial-fuel-cell electrodes: From conductive supports to active catalysts. Adv. Mater. 2017, 29, 1602547. [CrossRef]

108. Ghasemi, M.; Daud, W.R.W.; Hassan, S.H.A.; Oh, S.E.; Ismail, M.; Rahimnejad, M.; Jahim, J.M. Nano-structured carbon as electrode material in microbial fuel cells: A comprehensive review. J. Alloys Compd. 2013, 580, 245-255. [CrossRef]

109. Lamberg, P.; Bren, K.L. Extracellular electron transfer on sticky paper electrodes: Carbon paste paper anode for microbial fuel cells. ACS Energy Lett. 2016, 1, 895-898. [CrossRef]

110. Logan, B.; Cheng, S.; Watson, V.; Estadt, G. Graphite fiber brush anodes for increased power production in air-cathode microbial fuel cells. Environ. Sci. Technol. 2007, 41, 3341-3346. [CrossRef]

111. Santoro, C.; Guilizzoni, M.; Correa Baena, J.P.; Pasaogullari, U.; Casalegno, A.; Li, B.; Babanova, S.; Artyushkova, K.; Atanassov, P. The effects of carbon electrode surface properties on bacteria attachment and start up time of microbial fuel cells. Carbon 2014, 67, 128-139. [CrossRef] 
112. Penteado, E.D.; Fernandez-Marchante, C.M.; Zaiat, M.; Gonzalez, E.R.; Rodrigo, M.A. Influence of carbon electrode material on energy recovery from winery wastewater using a dual-chamber microbial fuel cell. Environ. Technol. 2017, 38, $1333-1341$. [CrossRef]

113. Kipf, E.; Koch, J.; Geiger, B.; Erben, J.; Richter, K.; Gescher, J.; Zengerle, R.; Kerzenmacher, S. Systematic screening of carbon-based anode materials for microbial fuel cells with Shewanella oneidensis MR-1. Bioresour. Technol. 2013, 146, 386-392. [CrossRef] [PubMed]

114. Zhou, M.; Chi, M.; Luo, J.; He, H.; Jin, T. An overview of electrode materials in microbial fuel cells. J. Power Sources 2011, 196, 4427-4435. [CrossRef]

115. Guo, K.; Hidalgo, D.; Tommasi, T.; Rabaey, K. Pyrolytic carbon-coated stainless steel felt as a high-performance anode for bioelectrochemical systems. Bioresour. Technol. 2016, 211, 664-668. [CrossRef]

116. Kerzenmacher, S. Engineering of microbial electrodes. In Advances in Biochemical Engineering/Biotechnology; Springer: Berlin/Heidelberg, Germany, 2019; Volume 167, pp. 135-180.

117. Krieg, T.; Sydow, A.; Schröder, U.; Schrader, J.; Holtmann, D. Reactor concepts for bioelectrochemical syntheses and energy conversion. Trends Biotechnol. 2014, 32, 645-655. [CrossRef] [PubMed]

118. Cui, H.F.; Du, L.; Guo, P.B.; Zhu, B.; Luong, J.H.T. Controlled modification of carbon nanotubes and polyaniline on macroporous graphite felt for high-performance microbial fuel cell anode. J. Power Sources 2015, 283, 46-53. [CrossRef]

119. Chen, X.; Cui, D.; Wang, X.; Wang, X.; Li, W. Porous carbon with defined pore size as anode of microbial fuel cell. Biosens. Bioelectron. 2015, 69, 135-141. [CrossRef]

120. Flexer, V.; Jourdin, L. Purposely designed hierarchical porous electrodes for high rate microbial electrosynthesis of acetate from carbon dioxide. Acc. Chem. Res. 2020, 53, 311-321. [CrossRef]

121. Flexer, V.; Chen, J.; Donose, B.C.; Sherrell, P.; Wallace, G.G.; Keller, J. The nanostructure of three-dimensional scaffolds enhances the current density of microbial bioelectrochemical systems. Energy Environ. Sci. 2013, 6, 1291-1298. [CrossRef]

122. Nie, H.; Zhang, T.; Cui, M.; Lu, H.; Lovley, D.R.; Russell, T.P. Improved cathode for high efficient microbial-catalyzed reduction in microbial electrosynthesis cells. Phys. Chem. Chem. Phys. 2013, 15, 14290-14294. [CrossRef] [PubMed]

123. Cui, M.; Nie, H.; Zhang, T.; Lovley, D.; Russell, T.P. Three-dimensional hierarchical metal oxide-carbon electrode materials for highly efficient microbial electrosynthesis. Sustain. Energy Fuels 2017, 1, 1171-1176. [CrossRef]

124. Kim, K.R.; Kang, J.; Chae, K.J. Improvement in methanogenesis by incorporating transition metal nanoparticles and granular activated carbon composites in microbial electrolysis cells. Int. J. Hydrog. Energy 2017, 42, 27623-27629. [CrossRef]

125. Champigneux, P.; Delia, M.L.; Bergel, A. Impact of electrode micro- and nano-scale topography on the formation and performance of microbial electrodes. Biosens. Bioelectron. 2018, 118, 231-246. [CrossRef] [PubMed]

126. Chen, Z.; Zhou, J.; Wang, Y.; Wang, Y. Nano on micro: Tuning microbial metabolisms by nano-based artificial mediators to enhance and expand production of biochemicals. Curr. Opin. Biotechnol. 2020, 64, 161-168. [CrossRef]

127. Kaur, R.; Marwaha, A.; Chhabra, V.A.; Kim, K.H.; Tripathi, S.K. Recent developments on functional nanomaterial-based electrodes for microbial fuel cells. Renew. Sustain. Energy Rev. 2020, 119, 109551. [CrossRef]

128. Wang, W.; You, S.; Gong, X.; Qi, D.; Chandran, B.K.; Bi, L.; Cui, F.; Chen, X. Bioinspired nanosucker array for enhancing bioelectricity generation in microbial fuel cells. Adv. Mater. 2016, 28, 270-275. [CrossRef]

129. Hindatu, Y.; Annuar, M.S.M.; Gumel, A.M. Mini-review: Anode modification for improved performance of microbial fuel cell. Renew. Sustain. Energy Rev. 2017, 73, 236-248. [CrossRef]

130. Pinck, S.; Jorand, F.P.A.; Xu, M.; Etienne, M. Protamine promotes direct electron transfer between shewanella oneidensis cells and carbon nanomaterials in bacterial biocomposites. ChemElectroChem 2019, 6, 2398-2406. [CrossRef]

131. Jeon, M.S.; Jeon, Y.; Hwang, J.H.; Heu, C.S.; Jin, S.; Shin, J.; Song, Y.; Chang Kim, S.; Cho, B.K.; Lee, J.K.; et al. Fabrication of three-dimensional porous carbon scaffolds with tunable pore sizes for effective cell confinement. Carbon 2018, 130, 814-821. [CrossRef]

132. Bi, L.; Ci, S.; Cai, P.; Li, H.; Wen, Z. One-step pyrolysis route to three dimensional nitrogen-doped porous carbon as anode materials for microbial fuel cells. Appl. Surf. Sci. 2018, 427, 10-16. [CrossRef]

133. Hung, Y.H.; Liu, T.Y.; Chen, H.Y. Renewable coffee waste-derived porous carbons as anode materials for high-performance sustainable microbial fuel cells. ACS Sustain. Chem. Eng. 2019, 7, 16991-16999. [CrossRef]

134. Rethinasabapathy, M.; Lee, J.H.; Roh, K.C.; Kang, S.M.; Oh, S.Y.; Park, B.; Lee, G.W.; Cha, Y.L.; Huh, Y.S. Silver grass-derived activated carbon with coexisting micro-, meso- and macropores as excellent bioanodes for microbial colonization and power generation in sustainable microbial fuel cells. Bioresour. Technol. 2020, 300, 122646. [CrossRef]

135. Logan, B.E. Scaling up microbial fuel cells and other bioelectrochemical systems. Appl. Microbiol. Biotechnol. 2010, 85, 1665-1671. [CrossRef]

136. Blasco-Gómez, R.; Batlle-Vilanova, P.; Villano, M.; Balaguer, M.D.; Colprim, J.; Puig, S. On the edge of research and technological application: A critical review of electromethanogenesis. Int. J. Mol. Sci. 2017, 18, 874. [CrossRef]

137. Neubert, M.; Hauser, A.; Pourhossein, B.; Dillig, M.; Karl, J. Experimental evaluation of a heat pipe cooled structured reactor as part of a two-stage catalytic methanation process in power-to-gas applications. Appl. Energy 2018, 229, 289-298. [CrossRef]

138. Christodoulou, X.; Okoroafor, T.; Parry, S.; Velasquez-Orta, S.B. The use of carbon dioxide in microbial electrosynthesis: Advancements, sustainability and economic feasibility. J. CO2 Util. 2017, 18, 390-399. [CrossRef] 
139. Bian, B.; Bajracharya, S.; Xu, J.; Pant, D.; Saikaly, P.E. Microbial electrosynthesis from $\mathrm{CO}_{2}$ : Challenges, opportunities and perspectives in the context of circular bioeconomy. Bioresour. Technol. 2020, 302, 122863. [CrossRef] [PubMed]

140. Mateos, R.; Escapa, A.; San-Martín, M.I.; De Wever, H.; Sotres, A.; Pant, D. Long-term open circuit microbial electrosynthesis system promotes methanogenesis. J. Energy Chem. 2020, 41, 3-6. [CrossRef]

141. Enzmann, F.; Mayer, F.; Stöckl, M.; Mangold, K.M.; Hommel, R.; Holtmann, D. Transferring bioelectrochemical processes from H-cells to a scalable bubble column reactor. Chem. Eng. Sci. 2019, 193, 133-143. [CrossRef]

142. Miyake, T.; Oike, M.; Yoshino, S.; Yatagawa, Y.; Haneda, K.; Nishizawa, M. Automatic, sequential power generation for prolonging the net lifetime of a miniature biofuel cell stack. Lab Chip 2010, 10, 2574-2578. [CrossRef]

143. Kipf, E.; Sané, S.; Morse, D.; Messinger, T.; Zengerle, R.; Kerzenmacher, S. An air-breathing enzymatic cathode with extended lifetime by continuous laccase supply. Bioresour. Technol. 2018, 264, 306-310. [CrossRef]

144. Yu, J.; Tu, J.; Zhao, F.; Zeng, B. Direct electrochemistry and biocatalysis of glucose oxidase immobilized on magnetic mesoporous carbon. J. Solid State Electrochem. 2010, 14, 1595-1600. [CrossRef]

145. Zheng, J.; Xu, J.L.; Jin, T.B.H.; Wang, J.L.; Zhang, W.Q.; Hu, Y.X.; He, P.G.; Fang, Y.Z. Preparation of magnetic ordered mesoporous carbon composite and its application in direct electrochemistry of horseradish peroxidase. Electroanalysis 2013, 25, $2159-2165$. [CrossRef]

146. Trifonov, A.; Stemmer, A.; Tel-Vered, R. Carbon-coated magnetic nanoparticles as a removable protection layer extending the operation lifetime of bilirubin oxidase-based bioelectrode. Bioelectrochemistry 2021, 137, 107640. [CrossRef] [PubMed]

147. Diender, M.; Uhl, P.S.; Bitter, J.H.; Stams, A.J.M.; Sousa, D.Z. High rate biomethanation of carbon monoxide-rich gases via a thermophilic synthetic coculture. ACS Sustain. Chem. Eng. 2018, 6, 2169-2176. [CrossRef] [PubMed]

148. Thema, M.; Weidlich, T.; Hörl, M.; Bellack, A.; Mörs, F.; Hackl, F.; Kohlmayer, M.; Gleich, J.; Stabenau, C.; Trabold, T.; et al. Biological $\mathrm{CO}_{2}$-methanation: An approach to standardization. Energies 2019, 12, 1670. [CrossRef]

149. Wang, H.; Ren, Z.J. A comprehensive review of microbial electrochemical systems as a platform technology. Biotechnol. Adv. 2013, 31, 1796-1807. [CrossRef]

150. Herkendell, K.; Stemmer, A.; Tel-Vered, R. Magnetically induced enzymatic cascades-advancing towards multi-fuel direct/mediated bioelectrocatalysis. Nanoscale Adv. 2019, 1, 1686-1692. [CrossRef]

151. Chiranjeevi, P.; Bulut, M.; Breugelmans, T.; Patil, S.A.; Pant, D. Current trends in enzymatic electrosynthesis for $\mathrm{CO}_{2}$ reduction. Curr. Opin. Green Sustain. Chem. 2019, 16, 65-70. [CrossRef]

152. Dubrawski, K.L.; Shao, X.; Milton, R.D.; Deutzmann, J.S.; Spormann, A.M.; Criddle, C.S. Microbial battery powered enzymatic electrosynthesis for carbon capture and generation of hydrogen and formate from dilute organics. ACS Energy Lett. 2019, 4, 2929-2936. [CrossRef]

153. Bhattacharjee, U.; Pandey, L.M. Novel nanoengineered materials-based catalysts for various bioelectrochemical systems. ACS Symp. Ser. 2020, 1342, 45-71. [CrossRef]

154. Zhai, T.; Wang, C.; Gu, F.; Meng, Z.H.; Liu, W.; Wang, Y. Dopamine/Polyethylenimine-Modified Silica for Enzyme Immobilization and Strengthening of Enzymatic $\mathrm{CO}_{2}$ Conversion. ACS Sustain. Chem. Eng. 2020, 8, 15250-15257. [CrossRef]

155. Wu, R.; Zhu, Z. Self-powered enzymatic electrosynthesis of 1-3,4-dihydroxyphenylalanine in a hybrid bioelectrochemical system. ACS Sustain. Chem. Eng. 2018, 6, 12593-12597. [CrossRef]

156. Sahoo, P.C.; Pant, D.; Kumar, M.; Puri, S.K.; Ramakumar, S.S.V. Material-microbe interfaces for solar-driven $\mathrm{CO}_{2}$ bioelectrosynthesis. Trends Biotechnol. 2020, 38, 1245-1261. [CrossRef]

157. Mazurenko, I.; Etienne, M.; Kohring, G.W.; Lapicque, F.; Walcarius, A. Enzymatic bioreactor for simultaneous electrosynthesis and energy production. Electrochim. Acta 2016, 199, 342-348. [CrossRef]

158. Hoa, L.Q.; Vestergaard, M.C.; Tamiya, E. Carbon-based nanomaterials in biomass-based fuel-fed fuel cells. Sensors 2017, 17, 2587. [CrossRef] [PubMed]

159. Sharma, M.; Sarma, P.M. Microbially mediated electrosynthesis processes. In Microbial Fuel Cell: A Bioelectrochemical System that Converts Waste to Watts; Springer: Berlin/Heidelberg, Germany, 2017; pp. 421-442. ISBN 9783319667935.

160. Foley, J.M.; Rozendal, R.A.; Hertle, C.K.; Lant, P.A.; Rabaey, K. Life cycle assessment of high-rate anaerobic treatment, microbial fuel cells, and microbial electrolysis cells. Environ. Sci. Technol. 2010, 44, 3629-3637. [CrossRef] [PubMed]

161. Rosenbaum, M.A.; Franks, A.E. Microbial catalysis in bioelectrochemical technologies: Status quo, challenges and perspectives. Appl. Microbiol. Biotechnol. 2014, 98, 509-518. [CrossRef] [PubMed] 